\title{
LETTER
}

\section{Management of sodium disorders during continuous haemofiltration}

\author{
Marlies Ostermann*, Helen Dickie, Linda Tovey and David Treacher
}

\begin{abstract}
In patients with acute kidney injury and concomitant severe hyponatraemia or hypernatraemia, rapid correction of the serum $\mathrm{Na}^{+}$concentration needs to be avoided. The present paper outlines the principles of how to adjust the $\mathrm{Na}^{+}$concentration in the replacement fluid during continuous renal replacement therapy to prevent rapid changes of the serum $\mathrm{Na}^{+}$concentration.
\end{abstract}

\section{Introduction}

Continuous venovenous haemofiltration $(\mathrm{CVVH})$ is an established treatment for patients with acute kidney injury. During CVVH, serum electrolyte concentrations tend to equilibrate with their concentrations in the replacement fluid. The rate at which this happens depends on the difference in their concentrations between serum and replacement fluid, and on the rate of treatment.

Patients presenting with acute kidney injury may have concomitant severe hyponatraemia or hypernatraemia. Over-rapid correction of the serum $\mathrm{Na}^{+}$concentration is associated with pontine myelinosis and/or cerebral oedema [1,2]. If CVVH is needed, the $\mathrm{Na}^{+}$concentration in the replacement fluid (usually $140 \mathrm{mmol} / \mathrm{l}$ ) needs to be adjusted in order to avoid rapid changes of the serum $\mathrm{Na}^{+}$ concentration. In the present paper we provide some guidance on how to make these adjustments for CVVH. The same principle could be applied for continuous haemodialysis or diafiltration.

\section{Acute kidney injury and hypernatraemia $\left(\mathrm{Na}^{+}>155 \mathrm{mmol} / \mathrm{l}\right)$}

Free water hydration is the first-line therapy if possible. If $\mathrm{CVVH}$ is necessary, the $\mathrm{Na}^{+}$concentration of the replacement fluid should be increased by adding concentrated $\mathrm{NaCl}$ solution (Table 1 ).

Generally, it is not considered safe to lower the serum $\mathrm{Na}^{+}$concentration by more than 8 to $10 \mathrm{mmol} / \mathrm{l}$ over 24 hours, especially in the setting of chronic hypernatraemia [1]. Usually, a stepwise correction of the patient's serum $\mathrm{Na}^{+}$concentration is planned using replacement fluid made up to successively lower $\mathrm{Na}^{+}$concentrations.

If the serum $\mathrm{Na}^{+}$decreases by $>2 \mathrm{mmol} / \mathrm{l}$ in 6 hours, either the rate of filtration should be decreased or the fluid bags should be changed to bags with a higher $\mathrm{Na}^{+}$ concentration.

The volumes of $30 \% \mathrm{NaCl}$ added are small and will not affect the concentration of other electrolytes in the solution significantly.

\section{Acute kidney injury and hyponatraemia $\left(\mathrm{Na}^{+}<125 \mathrm{mmol} / \mathrm{l}\right)$}

If $\mathrm{CVVH}$ is needed, the $\mathrm{Na}^{+}$concentration of the replacement fluid should be reduced by adding sterile water (Table 2). Generally, it is not considered safe to increase the serum $\mathrm{Na}^{+}$concentration by more than 8 to $10 \mathrm{mmol} / \mathrm{l}$ over 24 hours, especially in chronic hyponatraemia [2]. Usually, a stepwise correction of the patient's serum $\mathrm{Na}^{+}$ concentration is planned using replacement fluid made up to successively higher $\mathrm{Na}^{+}$concentrations.

If the serum $\mathrm{Na}^{+}$concentration has increased by $>2 \mathrm{mmol} / \mathrm{l}$ in 6 hours, either the rate of filtration should

Table 1. Effect of adding different volumes of $30 \% \mathrm{NaCl}$ to replacement fluid

\begin{tabular}{|c|c|c|c|c|c|}
\hline Volume of $30 \% \mathrm{NaCl}$ added & Nil & $\begin{array}{c}5 \mathrm{ml} \\
\left(=25 \mathrm{mmol} \mathrm{Na}^{+}\right)\end{array}$ & $\begin{array}{c}10 \mathrm{ml} \\
(=50 \mathrm{mmol} \mathrm{Na})^{+}\end{array}$ & $\begin{array}{c}15 \mathrm{ml} \\
(=75 \mathrm{mmol} \mathrm{Na})^{+}\end{array}$ & $\begin{array}{c}20 \mathrm{ml} \\
\left(=100 \mathrm{mmol} \mathrm{Na}^{+}\right)\end{array}$ \\
\hline Final $\mathrm{Na}^{+}$concentration in replacement fluid & $140 \mathrm{mmol} / \mathrm{l}$ & $145 \mathrm{mmol} / \mathrm{l}$ & $150 \mathrm{mmol} / \mathrm{l}$ & $155 \mathrm{mmol} / \mathrm{l}$ & $160 \mathrm{mmol} / \mathrm{l}$ \\
\hline
\end{tabular}

Effect of adding different volumes of $30 \% \mathrm{NaCl}(\approx 5 \mathrm{mmol} / \mathrm{ml})$ to a $5 \mathrm{I}$ bag of replacement fluid containing a $\mathrm{Na}^{+}$concentration of $140 \mathrm{mmol} / \mathrm{l}$.

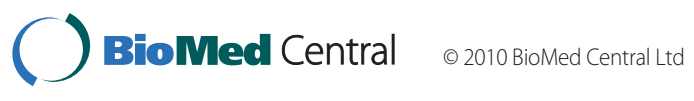

*Correspondence: Marlies.Ostermann@gstt.nhs.uk Guy's \& St Thomas' Foundation Trust, Department of Critical Care, Westminster Bridge Road, London SE17EH, UK 
Table 2. Effect of adding different volumes of water to replacement fluid

\begin{tabular}{|c|c|c|c|c|}
\hline $\begin{array}{l}\text { Volume of water } \\
\text { added (ml) }\end{array}$ & $\begin{array}{l}\text { Final volume of diluted } \\
\text { replacement fluid (I) }\end{array}$ & $\begin{array}{l}{\left[\mathrm{Na}^{+}\right] \text {in diluted }} \\
\text { replacement fluid (mmol/l) }\end{array}$ & $\begin{array}{l}{\left[\mathrm{HCO}_{3}^{-}\right] \text {in diluted }} \\
\text { replacement fluid ( } \mathrm{mmol} / \mathrm{l})\end{array}$ & $\begin{array}{l}{\left[\mathrm{K}^{+}\right] \text {in diluted replacement }} \\
\text { fluid containing } 4 \mathrm{mmol} / \mathrm{l}\end{array}$ \\
\hline Nil & 5 & 140 & 35 & 4.0 \\
\hline 150 & 5.15 & 136 & 34 & 3.9 \\
\hline 250 & 5.25 & 133 & 33 & 3.8 \\
\hline 350 & 5.35 & 131 & 33 & 3.7 \\
\hline 500 & 5.5 & 127 & 32 & 3.6 \\
\hline 750 & 5.75 & 122 & 30 & 3.5 \\
\hline 1,000 & 6.0 & 117 & 29 & 3.3 \\
\hline 1,250 & 6.25 & 112 & 28 & 3.2 \\
\hline
\end{tabular}

Effect of adding different volumes of water to a $5 \mathrm{I} \mathrm{bag} \mathrm{of} \mathrm{replacement} \mathrm{fluid} \mathrm{with} \mathrm{a} \mathrm{Na}^{+}$concentration of $140 \mathrm{mmol} / \mathrm{l}$. $\left[\mathrm{Na}^{+}\right]$, sodium concentration; [ $\left.\mathrm{HCO}_{3}{ }^{-}\right]$, bicarbonate concentration; $\left[\mathrm{K}^{+}\right]$, potassium concentration.

be decreased or the fluid bags should be changed to bags with a lower $\mathrm{Na}^{+}$concentration.

The concentration of bicarbonate and potassium in the final solution will also be reduced, and the patient may need additional supplementation.

Abbreviations

$\mathrm{CVH}$, continuous venovenous haemofiltration.

\section{Acknowledgements}

The authors would like to thank the ICU pharmacists at Guy's \& St Thomas' Hospital for their contribution. The project was supported by internal departmental funds.

\section{Competing interests}

The authors declare that they have no completing interests.

Published: 27 May 2010

References

1. Adrogué HJ, Madias NE: Hypernatremia. N Eng/ J Med 2000, 342:1493-1499.

2. Adrogué HJ, Madias NE: Hyponatremia. N Engl J Med 2000, 342:1581-1589.

doi:10.1186/cc9002

Cite this article as: Ostermann M, et al:: Management of sodium disorders during continuous haemofiltration. Critical Care 2010, 14:418. 